FRANCISZEK CHWALEWSKI* - LUBLIN

\title{
BUDOWA BIBLIOTEKI UNIWERSYTECKIEJ I DOMU PROFESORÓW KATOLICKIEGO UNIWERSYTETU LUBELSKIEGO PRZY UL. CHOPINA W LATACH 1947-1950
}

Przed siedemdziesięciu laty, w 1947 roku, biskup Stefan Wyszyński - ówczesny ordynariusz diecezji lubelskiej, na prośbę Rektora KUL ks. Antoniego Słomkowskiego - przekazał Uniwersytetowi duży budynek przy ul. Chopina 27 i wyraził zgodę na przekształcenie go w bibliotekę uniwersytecką oraz mieszkania dla profesorów. Gmach ten został wzniesiony (w stanie surowym) przez diecezję lubelską w latach 1937-1939 jako przyszła siedziba Akcji Katolickiej. Wybuch wojny, okres okupacji i sytuacja w Polsce po 1944 roku wstrzymały dalsze prace.

Aby wyjaśnić tę decyzję bpa S.Wyszyńskiego, pragnę przedstawić w skrócie historię tego budynku, jego przeznaczenie oraz osobę inicjatora inwestycji, ponieważ opracowania na ten temat są fragmentaryczne lub nieścisłe.

Pomysł wybudowania domu katolickiego powstał w Kurii Biskupiej z inicjatywy bpa Mariana Fulmana. Prośbę pisemną do władz miasta Lublina podpisał i złożył Wikariusz Generalny ks. prałat Ludwik Kwiek. W dodatkowym piśmie przesłanym przez Kurię do Prezydenta Lublina jest informacja, że „dom katolicki będzie przeznaczony dla Akcji Katolickiej i organizacji służących celom religijno-społecznym, a zatem będzie miał charakter użyteczności publicznej”". Pozwolenie na budowę domu zostało wydane przez władze miasta na początku 1938 roku. Biskup M. Fulman powołał przy Kurii, Komitet Budowy Domu Katolickiego w Lublinie z udziałem ks. dra Antoniego Pobożnego oraz przydzielił na ten cel dużą działkę (ok. 39 arów) przy ul. Chopina 25-27, która była własnością Kurii. Z prośbą o opracowanie projektu i nadzór nad jego realizacją zwrócono się do znanego inż. arch. Jerzego Siennickiego, który w latach trzydziestych z inicjatywy bpa Fulmana zaplanował gmach gimnazjum biskupiego na Czwartku. Po zatwierdzeniu projektu domu katolickiego o kubaturze ok. $25.000 \mathrm{~m}^{3}$,

* Franciszek Chwalewski - emerytowany starszy kustosz Biblioteki Uniwersyteckiej KUL; odznaczony medalem ,Za Zasługi dla KUL”.

${ }^{1}$ Archiwum Państwowe w Lublinie (dalej: APL), sygn. 5318, Akta nieruchomości położonej w Lublinie przy ul. Chopina 27, Akta miasta Lublina, Inspekcja Budowlana. 
z przewidywaną dużą salą widowiskową dla 929 osób (461 osób na galerii oraz 468 osób na parterze) ze sceną, kabiną kinooperatora, trzema klatkami schodowymi, z dwoma zapasowymi wyjściami, przestronnym hallem oraz salą zebrań dla 215 osób, bardzo szybko przystąpiono do prac budowlanych. Przed wybuchem wojny zdołano postawić szkielet budynku, ściany i wszystko przykryć dachem. W drugiej części gmachu - przyszłym Domu Biurowym Akcji Katolickiej - o kubaturze $10.500 \mathrm{~m}^{3}$, wykonano w 1939 roku fundamenty, strop nad piwnicami i część ścian do wysokości pierwszego piętra. Łączna kubatura planowanej inwestycji wynosiła ok. $35.000 \mathrm{~m}^{3}$. Wybuch wojny spowodował przerwanie dalszych prac budowlanych.

W czasie okupacji część pomieszczeń domu przy ul. Chopina 27 (od strony podwórza) Niemcy wykorzystywali dla swojej zbrodniczej działalności. Z przekazów ustnych oraz ustaleń Polsko-Sowieckiej Komisji Nadzwyczajnej dla Zbadania Zbrodni Niemieckich w obozie na Majdanku (w Lublinie) - do której obok przedstawicieli władz i rzeczoznawców wchodzili: prezes Polskiego Czerwonego Krzyża w Lublinie adwokat Ludwik Chrystians, ks. prałat Józef Kruszyński (były Rektor KUL) oraz profesorowie: Mieczysław Popławski i Leon Białkowski, wynika, że dom przy ul. Chopina był bazą, gdzie sortowano zrabowane więźniom i mieszkańcom miasta rzeczy i przygotowywano je do wysłania do Niemiec ${ }^{2}$. Należy dodać, że w pobliżu, przy ul. Lipowej istniała filia niemieckiego obozu koncentracyjnego na Majdanku (w roku 2007 wybudowano w miejscu podobozu Centrum Handlowe „Plaza”).

Z zeznań zbrodniarzy hitlerowskich na procesie w Norymberdze wiemy, że w toku „operacji Rainhardt” w latach 1942-1943 Niemcy wywieźli z Lublina wiele cennych przedmiotów oraz 1901 wagonów materiałów włókienniczych (odzieży, bielizny, pierza) $)^{3}$. Fotografia z roku 1944 odnaleziona w Państwowym Muzeum na Majdanku, przedstawiająca grupę zagranicznych dziennikarzy, którzy na podwórzu przed budynkiem przyszłej biblioteki oglądają resztki zniszczonych rzeczy (opakowań), wskazuje, że był tutaj magazyn niemiecki. Prawdopodobnie część pomieszczeń w budynku przy ul. Chopina była okresowo zajmowana przez firmę budowlaną lubelskiego architekta Bohdana Kelles-Krauzego ${ }^{4}$. W końcu lipca 1944 roku do Lublina wkroczyły wojska sowieckie, zmuszając dotychczasowego okupanta niemieckiego do opuszczenia miasta. Wszystkie większe obiekty w mieście, lokale użyteczności publicznej, w tym również gmach uniwersytecki i budynek przy ul. Chopina, zostały zajęte przez wojska sowieckie. Po krótkim ich pobycie w nieukończonym budynku, gmach wrócił do prawowitego właściciela Lubelskiej Kurii Diecezjalnej.

Biskup M. Fulman, po szczęśliwym powrocie do Lublina 19 lutego 1945 roku, z obozu koncentracyjnego w Oranienburgu, gdzie skazano go na karę śmierci

${ }^{2}$ Komunikat Polsko-Sowieckiej Komisji Nadzwyczajnej dla Zbadania Zbrodni Niemieckich dokonanych w obozie zniszczenia na Majdanku w m. Lublinie, „, Rzeczpospolita”, 1944, nr 45, s. 4-6.

${ }^{3}$ S. Piotrowski, Misja Odyla Globocnika. Sprawozdanie o wynikach finansowych zagłady Żydów w Polsce, Warszawa 1949, s. 34-35.

${ }^{4}$ J. Jaźwierska, $Z$ dziejów przebudowy gmachu Biblioteki Uniwersyteckiej KUL, „Roczniki Humanistyczne", 55 (2007) z. 4, s. 94. 
(wyjątkowo wyrok nie został wykonany), oraz po okresie internowania w Nowym Sączu, rozpoczął pracę w diecezji wśród zniszczeń wojennych. W liście pasterskim z dnia 14 września 1945 roku pisał, że „miast kończyć zaczęty w 1938 roku wielki Dom Diecezjalny Akcji Katolickiej w Lublinie", prosi księży i diecezjan, aby wsparli swoim groszem „,zaczęte dzieło odnowienia naszej Lubelskiej Katedry"5. Biskup M. Fulman (1866-1945), zarządzający diecezją lubelską od chwili odzyskania niepodległości Polski w 1918 roku, znany był jako utalentowany duszpasterz, uczony, pedagog, redaktor, dobry organizator, działacz społeczny i wielki patriota. W dniu 9 listopada 1931 roku został odznaczony przez Prezydenta Rzeczypospolitej Polskiej Ignacego Mościckiego Krzyżem Komandorskim z Gwiazdą Orderu Odrodzenia Polski. Biskup Fulman zaliczany jest do grupy najwybitniejszych biskupów Polski międzywojennej. Był przyjacielem Rektora KUL ks. Idziego Radziszewskiego, współorganizatorem KUL-u oraz jego pierwszym Wielkim Kanclerzem. Należał do twórców stowarzyszenia „Akcji Katolickiej" w diecezji.

W związku z rozwojem apostolstwa ludzi świeckich w diecezji, w dniu 6 lipca 1932 roku erygował Diecezjalny Instytut Akcji Katolickiej w Lublinie ${ }^{6}$. Prezesem Instytutu został Stefan Smólski, wiceprezesem Stanisław Starowieyski (od 1935 prezes), dyrektorem - ks. dr Zygmunt Surdacki, a asystentem kościelnym - ks. prof. Antoni Szymański (Rektor KUL w latach 1933-1942), zaś od roku 1938 asystentem kościelnym został bp Władysław Goral, sufragan lubelski.

Od początku powstania Akcji Katolickiej, trwały prace organizacyjne, religijno-wychowawcze oraz oświatowe $w$ dekanatach i parafiach. O pracy i osiągnięciach Akcji Katolickiej w diecezji w latach 1933-1939 informowało „Ogniwo" - okólnik, a od roku 1936 czasopismo. W roku 1935 powstała Diecezjalna Rada Akcji Katolickiej, jako organ wnioskodawczy i opiniotwórczy. W skład Rady wszedł Stanisław Starowieyski ${ }^{7}$, ziemianin z Łaszczowa, gorliwy i ofiarny katolik zaangażowany $\mathrm{w}$ prace stowarzyszenia, szczególnie na terenie powiatu Tomaszów Lubelski i południowej Lubelszczyzny. Do dyspozycji Akcji Katolickiej bp Fulman oddał budynek należący do Kurii Biskupiej przy ul. Zielonej 3 (obok kościoła św. Jozafata). Tutaj miało swoje pomieszczenie Biuro Akcji Katolickiej, gdzie urzędował ks. dyr. Zygmunt Surdacki (zamordowany w Oświęcimiu w 1942 roku). Co pewien czas przyjeżdżał z Łaszczowa i zatrzymywał się w Biurze na parę dni Stanisław Starowieyski, by wykonać prace związane z pełnioną funkcją prezesa (zebrania Rady Diecezjalnej, konferencje, kursy, zjaz-

${ }^{5}$ List J.E. ks. Bpa M.L. Fulmana w sprawie odbudowy Katedry Lubelskiej, „Wiadomości Diecezjalne Lubelskie", 1-2 (1945) s. 10.

${ }^{6}$ Erekcja Diecezjalnego Instytutu Akcji Katolickiej w Lublinie, „Wiadomości Diecezjalne Lubelskie", 7 (1932) s. 208

${ }^{7}$ Stanisław Kostka Starowieyski (1895-1941) - ziemianin z Łaszczowa, ojciec rodziny, działacz Akcji Katolickiej. Prezes Diecezjalnego Instytutu Akcji Katolickiej w Lublinie, szambelan Ojca Św. Piusa XI. W dniu 19 czerwca 1940 roku został aresztowany przez Gestapo i uwięziony w Rotundzie Zamojskiej, potem na Zamku Lubelskim, a następnie przewieziony do obozu koncentracyjnego w Dachau, gdzie zmarł w dniu 13 kwietnia 1941 roku. Papież Jan Paweł II beatyfikował go 13 czerwca 1999 roku, wśród 108 Męczenników z okresu II wojny światowej. 
dy, na których zawsze wygłaszał referaty) ${ }^{8}$. Z myślą o potrzebach stowarzyszenia bp M. Fulman rozpoczął budowę Domu Katolickiego, który miał być centralnym ośrodkiem działalności Akcji Katolickiej w diecezji. W związku z apelem papieża Piusa XI, po 1930 roku zaczęło się rozwijać również w Polsce stowarzyszenie Akcja Katolicka, czyli zorganizowane apostolstwo ludzi świeckich połączone organizacyjnie ze strukturą hierarchiczną Kościoła Katolickiego dla obrony zasad religijnych i moralnych oraz dla dobra narodu polskiego. Statut Akcji Katolickiej Diecezji Lubelskiej wskazał ogólne kierunki pracy Akcji Katolickiej, formułując je w kilku paragrafach:

(§1) Zadaniem Akcji Katolickiej w diecezji jest zespolenie, zorganizowanie, wyrobienie zrzeszeń katolickich dla celów apostolstwa świeckiego, czyli dla pogłębienia i szerzenia, wprowadzania w czyn i obrony zasad katolickich w życiu jednostki, rodziny i społeczeństwa, zgodnie z nauką Kościoła Katolickiego ze wskazaniami Stolicy Św.

(§2) A.K. stoi poza i ponad partiami politycznymi.

(§3) A.K. w diecezji pozostaje w bezpośredniej zależności od Biskupa Ordynariusza 9 .

W planowanym domu, obok wielkiej sali (kinoteatru), która pozwalałaby na organizowanie zjazdów, okolicznościowych uroczystości, wykładów, konferencji, spotkań o charakterze religijno-wychowawczym, wyświetlanie filmów, wystawianie sztuk teatralnych oraz propagowanie akcji charytatywnych, miały powstać pomieszczenia dla biur rozbudowywanego stowarzyszenia Akcji Katolickiej, w skład którego wchodziły cztery organizacje zwane Kolumnami: Mężów, Kobiet, Młodzieży Męskiej i Młodzieży Żeńskiej. Zamierzano utworzyć kaplicę, bibliotekę, czytelnię, księgarnię, poradnię dla rodziców, mieszkania dla dyrekcji Akcji Katolickiej i pracowników administracyjnych, pomieszczenia służbowe, pokoje gościnne oraz stołówkę. Podobne domy dla Akcji Katolickiej w latach trzydziestych wybudowano w Warszawie, Krakowie oraz w innych miastach, stolicach diecezji. Były one ważnymi ośrodkami kultury oraz służyły pomocą w pracy stowarzyszenia dla zespolenia wielu środowisk społecznych w jedną rodzinę chrześcijańską i narodową. Po roku 1944 stowarzyszenie zostało zdelegalizowane przez władze państwowe ${ }^{10}$.

Po wojnie, jak wspomniano, bp M. Fulman po powrocie z internowania podjął energicznie pracę w diecezji. Obok pełnienia obowiązków duszpasterskich, troszczył się o odbudowę Katedry i innych budowli sakralnych; służył też radą i pomocą Katolickiemu Uniwersytetowi Lubelskiemu. Zwrócił się również z prośbą do redakcji „Wiadomości Diecezjalnych Lubelskich” o wznowienie wydawanego od

${ }^{8}$ Z. Kulik, Bt. Stanisław Kostka Starowieyski 1895-1941 działacz Akcji Katolickiej, Sandomierz 2015, s. 178-179

${ }^{9}$ Statut Akcji Katolickiej Diecezji Lubelskiej, „Wiadomości Diecezjalne Lubelskie”, 7 (1932) s. $209-217$

${ }^{10} \mathrm{~W}$ wyniku przemian ustrojowych w Polsce po 1989 roku, na apel papieża Jana Pawła II skierowany do biskupów polskich w roku 1993, zostało reaktywowane stowarzyszenie „Akcja Katolicka”. W archidiecezji lubelskiej stowarzyszenie zostało wznowione w 1995 roku. Na asystenta kościelnego i dyrektora Instytutu Akcji Katolickiej został powołany ks. dr Ryszard Podpora. 
roku 1918 czasopisma, które obok umieszczania rozporządzeń władzy biskupiej służyło pomocą w budowaniu wspólnoty religijnej w diecezji.

W dniu 14 czerwca 1945 roku Rektor KUL ks. A. Słomkowski, Senat Akademicki i młodzież akademicka witali z wielką serdecznością i wdzięcznością bpa Mariana Fulmana w murach Uczelni. Nawiązując do jubileuszu 50-lecia Jego kapłaństwa, który przypadał w maju 1939 roku, ale nie mógł być świętowany z powodu choroby Jubilata, a następnie na skutek wojny i okupacji, Uniwersytet wręczył swojemu Wielkiemu Kanclerzowi, wydaną przez Towarzystwo Naukowe KUL w roku 1939 ku Jego czci trzytomową Księgę Pamiatkowa. Do tego dzieła została dołączona okolicznościowa dedykacja ówczesnego Rektora KUL ks. Antoniego Szymańskiego „(...) jako wyraz głębokiego hołdu, szczerej wdzięczności i serdecznego przywiązania (...)"11. Niezależnie od wspomnianych wyrazów uznania, Senat KUL w dniu 14 czerwca wręczył Jubilatowi dyplom doktoratu honoris causa $\mathrm{w}$ dziedzinie teologii, przyznany jeszcze przed wojną, $\mathrm{w}$ dniu 6 maja 1939 roku. W trakcie tej uroczystości przypomniano, że wraz z poprzednimi Rektorami KUL, bp M. Fulman przez ponad 25 lat otaczał Uniwersytet troską i pomagał w rozwiązywaniu wielu ważnych i trudnych spraw. Należy podkreślić, że biskup w okresie międzywojennym interesował się i wspomagał działalność apostolską Akcji Katolickiej w diecezji, która przynosiła dobre owoce, między innymi, przez organizowanie uroczystości religijno-patriotycznych. Jedną $\mathrm{z}$ nich należy przypomnieć:

(...) Katolickie Stowarzyszenie Mężów m. Lublina i pow. lubelskiego zorganizowało w Lublinie w niedzielę dn. 26 czerwca 1938 roku podniosłą manifestację religijno-patriotyczną. Ponad 5 tys. mężów zgromadziło się, ażeby z racji swojego święta patronalnego oddać publicznie hołd Najśw.[iętszemu] Sercu Pana Jezusa oraz uczcić: a) 75 rocznicę Powstania 1863 r., b) 20-lecie sakry biskupiej J.E. Ks. Biskupa M. Fulmana, c) 20-lecie istnienia Kat.[olickiego] Uniwersytetu Lubelskiego (...) O godz. 9 Mszę św. polową na placu Katedralnym, przybranym w barwy papieskie i narodowe, celebrował J.E. Ks. Biskup M. Fulman. (...) Po Mszy św. ks. Biskup wygłosił do mężów kazanie, po czym dokonał poświęcenia dębowego krzyża olbrzymich rozmiarów. Krzyż ten długości 12 mtr. Mężczyźni wzięli na ramiona i udali się z nim pochodem ulicami m. Lublina na miejsce stracenia Powstańców 63 roku. Pochód ten był naprawdę imponujący. (...) Pochód ten, w skupieniu, z odkrytymi głowami, rozciągnięty na całej długości Krakowskiego Przedmieścia doszedł do mogiły Powstańców, znajdującej się w polu za kościołem garnizonowym. Tu na olbrzymim placu ustawił się cały garnizon lubelski, poczty sztandarowe, delegacje, duchowieństwo i tysiące mężczyzn. Po ustawieniu Krzyża, dyrektor DIAK-u ks. dr Z. Surdacki odmówił modlitwę, powtarzaną głośno przez tysiące ludzi za poległych w obronie Wiary i Ojczyzny. Orkiestra wojskowa odegrała marsza żałobnego (...).

${ }^{11}$ E. Walewander, Biskup Marian Leon Fulman (1866-1945) - zycie i dzieło w: Biskup Lubelski Marian Leon Fulman. Pedagog trudnych lat, red. E. Walewander, Lublin 2010, s. 128 
Po patriotycznym przemówieniu dowódcy garnizonu lubelskiego i odśpiewaniu pieśni «Boże coś Polskę» uroczystość pod krzyżem zakończono ${ }^{12}$.

W kilka miesięcy po spotkaniu jubileuszowym na KUL bp M. Fulman zmarł 18 grudnia 1945 roku. Został pochowany bardzo uroczyście w krypcie katedry lubelskiej. W pogrzebie wzięła udział kompania honorowa Wojska Polskiego.

Nowym ordynariuszem został mianowany w dniu 4 marca 1946 roku ks. Stefan Wyszyński, który w latach 1925-1929 studiował na KUL i uzyskał doktorat $\mathrm{z}$ prawa kanonicznego. Po manifestacyjnych uroczystościach ingresowych $\mathrm{w}$ dniu 26 maja 1946 roku rozpoczął on intensywną działalność duszpasterską, religijno-społeczną i naukową. Uczestniczył w licznych wizytacjach kanonicznych parafii, brał udział w rekolekcjach, wykładach dla różnych grup społecznych i zawodowych, młodzieży szkolnej i akademickiej, widząc potrzebę pogłębiania wiary i kultury religijnej wśród katolików świeckich. W tym celu wskrzesił w 1946 roku Instytut Wyższej Kultury Religijnej na KUL, powołany przez bpa M. Fulmana w 1938 roku. Działalność ta budziła wielkie zainteresowanie, podziw i wdzięczność społeczeństwa. W dniu 10 listopada 1946 roku bp S. Wyszyński zainaugurował na KUL działalność Wydziału Filozofii Chrześcijańskiej. Poza licznymi obowiązkami związanymi z urzędem biskupim, żywo interesował się odbudową Katedry i Seminarium Duchownego. Uczestniczył również w rozwiązywaniu wielu trudnych problemów gospodarczych, które powstały w wyniku wojny i przemian ustrojowych w Polsce.

W związku z likwidacją Akcji Katolickiej, powstał problem, co zrobić z nieukończonym Domem Katolickim przy ul. Chopina. W Kurii Biskupiej rozważano kilka wariantów rozstrzygnięcia tej sprawy. W tej sytuacji Rektor KUL ks. A. Słomkowski zwrócił się do bpa S. Wyszyńskiego, z prośbą o przekazanie tego budynku Katolickiemu Uniwersytetowi Lubelskiemu, który podejmie starania, aby go wykończyć ${ }^{13}$. Odpowiadając na tę prośbę, po konsultacji z księżmi dziekanami, bp S. Wyszyński zdecydował o przekazaniu nieukończonego Domu Akcji Katolickiej dla potrzeb Katolickiego Uniwersytetu Lubelskiego. Była to dla Uczelni decyzja ogromnej wagi. Realizując prośbę Rektora KUL, bp S. Wyszyński pragnął również ocalić i godnie wykorzystać wielkie dzieło bpa Fulmana, które nie

${ }^{12}$ „Wiadomości Diecezjalne Lubelskie”, 6-7 (1938) s. 225-226.

Podczas okupacji Niemcy dokonali w Polsce wielu zniszczeń i zbrodni. W pierwszej kolejności przystąpili do wyniszczenia przywódców narodu, inteligencji, duchowieństwa, działaczy społecznych i kulturalnych, osadzając ich w więzieniach i obozach koncentracyjnych, gdzie najczęściej byli mordowani. Wśród aresztowanych byli też organizatorzy i działacze Akcji Katolickiej. Z diecezji lubelskiej niemal wszyscy główni twórcy i kierownicy tej organizacji, którzy m.in. uczestniczyli w staraniach i pracach związanych z budową diecezjalnego Domu Katolickiego w Lublinie przy ul. Chopina, zostali aresztowani, a następnie zamordowani w obozach koncentracyjnych w Oświęcimiu, Oranienburgu i Dachau: bp Władysław Goral (beatyfikowany przez papieża Jana Pawła II w roku 1999), Stanisław Kostka Starowieyski (beatyfikowany w roku 1999), ks. Zygmunt Surdacki, ks. Antoni Pobożny. Jedynie bp Marian Fulman, został zwolniony z obozu koncentracyjnego, ale internowano go w miejscu odosobnienia poza diecezją lubelską. Winniśmy o nich i o wszystkich innych obrońcach Wiary i Ojczyzny ze czcią pamiętać.

${ }^{13}$ A. Słomkowski, Wspomnienia z czasów petnienia obowiazków Rektora KUL, w: Katolicki Uniwersytet Lubelski w latach 1944-1952, Lublin 1999, s. 62 
mogło być kontynuowane przez diecezję zgodnie z jego pierwotnymi zamiarami. Wynikało to z braku pozwolenia władz państwowych, jak również środków materialnych. Ordynariusz lubelski bp S. Wyszyński - wybitny mąż stanu i wielki obrońca Kościoła, miłośnik narodu polskiego i ziemi ojczystej (Prymas Tysiąclecia i Sługa Boży), znany był z zatroskania o przyszłość KUL. Będąc jego profesorem i Wielkim Kanclerzem, znał dobrze sytuację i trudności Uczelni w okresie powojennym. Wiedział, że brakuje mieszkań dla profesorów i pracowników, a dotychczasowe pomieszczenie Biblioteki Uniwersyteckiej w poklasztornym gmachu przy ul. Dolnej Panny Marii 4 jest w bardzo złym stanie. Rektor KUL ks. A. Słomkowski w okolicznościowym druku wydanym z okazji ingresu bpa S. Wyszyńskiego na stolicę arcybiskupią w Warszawie w lutym 1949 roku pisał:

Wielki Kanclerz miał jasne zdanie o konieczności istnienia uniwersytetu katolickiego w Polsce i o jego zadaniach. Stąd też popierał wszystko, co służyło uczelni, nawet gdy były to poczynania bardzo śmiałe, jak stworzenie mieszkań dla profesorów, pomieszczenia biblioteki uniwersyteckiej, zdobycie ośrodka w Konstantynowie. Nieraz za mało mu było inicjatywy władz uniwersyteckich i sam rzucał nowe myśli [...]. W Wielkim Kanclerzu uniwersytet znalazł nie tylko oddanego sobie zwierzchnika, ale i przyjaciela, który służył zawsze dobrą radą i pomocą ${ }^{14}$.

W związku z decyzją bpa S. Wyszyńskiego odnośnie Domu Katolickiego zaakceptowaną przez Senat Akademicki oraz po uzgodnieniu przez KUL spraw własnościowo-prawnych z Kurią Biskupią w Lublinie ${ }^{15}$, władze Uczelni w dniu

${ }^{14}$ A. Słomkowski, Wielki Kanclerz K.U.L., w: „Na Ingres ks. Prymasa, Jednodniówka Katolicka", 6 II 1949, Warszawa 1949.

${ }^{15}$ Po przemianach politycznych w Polsce w roku 1989, władze KUL oraz dyrekcja Biblioteki Uniwersyteckiej podjęły starania o rozbudowę gmachu biblioteki na działce przy ul. Chopina 2729. W związku z tym w siedzibie Kurii Metropolitalnej w Lublinie w dniu 15 XII 1994 r. został sporządzony przez notariusza Akt Notarialny dotyczący umowy darowizny działki przy ul. Chopina 27-29 w którym uczestniczyli Metropolita Lubelski abp prof. Bolesław Pylak - tamże zamieszkały - działający w imieniu i na rzecz Katolickiego Uniwersytetu Lubelskiego, jako Wielki Kanclerz - na podstawie uprawnień statutowych oraz bp Ryszard Karpiński - proboszcz parafii archikatedralnej działający w imieniu parafii gdyż w Księdze Wieczystej parafia archikatedralna była wpisana jako jej właściciel. Ks. bp Ryszard Karpiński oświadczył, że daruje Katolickiemu Uniwersytetowi Lubelskiemu nieruchomość o powierzchni 39 arów i $61 \mathrm{~m}^{2}$ zabudowaną budynkiem Biblioteki KUL, który to budynek został wzniesiony kosztem i nakładem KUL. Wielki Kanclerz abp prof. B. Pylak oświadczył, że darowiznę tę na rzecz Katolickiego Uniwersytetu Lubelskiego przyjmuje.

Na prośbę Władz Uniwersytetu i Dyrekcji Biblioteki KUL, skierowanej do Kurii Diecezjalnej w Lublinie, w dniu 5 VI 1997 r. został sporządzony dodatkowy Akt Notarialny w którym uczestniczyli abp B. Pylak oraz bp R. Karpiński, dotyczący przekazania dla KUL odzyskanych fragmentów działki przy ul. Chmielarczyka i Lipowej o powierzchni 3 arów i $88 \mathrm{~m}^{2}$ która była bezprawnie zawłaszczona przez władze miasta Lublina w latach 50 . XX wieku. Dokumenty urzedowe sprzed 1939 r. odnalezione w Archiwum Państwowym w Lublinie przez pracowników Biblioteki Uniwersyteckiej KUL, wskazują, że jest to własność Kościoła. AU KUL, Akta; APL, Plany.

Decyzja o zwrocie działki zobowiązywała władze miasta Lublina, do zmiany dotychczasowej lokalizacji ul. Chmielarczyka, która była częściowo wybudowana na terenie należącym do Kościoła. Odzyskana powierzchnia gruntu znacząco ułatwiła budowę nowego skrzydła Biblioteki, przy- 
29 kwietnia 1947 roku zwróciły się do Zarządu Miasta Lublina - Wydziału Budonictwa z prośbą „o przedłużenie ważności planów budowlanych zatwierdzonych w 1938 roku dotyczących budowli na posesji Kurii Lubelskiej”. W odpowiedzi z dnia 30 maja 1947 roku przesłanej do KUL Zarząd Miejski w Lublinie, Wydział Budownictwa informuje, że ważność planu budowli na posesji Kurii Biskupiej Lubelskiej może być przedłużona „o ile plany te w zupełności odpowiadają potrzebom uniwersytetu katolickiego". Zarząd przekazał również informację, że nie posiada potrzebnych planów (istnieje tylko plan domu biurowego w jednym egzemplarzu), w związku z tym dla uzyskania ponownego zatwierdzenia budowy należy przedłożyć plany $\mathrm{w}$ skali 1:100 w dwóch egzemplarzach $\mathrm{w}$ przepisanej formie. Plany te jednak „winny wykazać zgodność z istniejącym stanem budowy oraz wszystkie zmiany i urządzenia wewnętrzne, jakie zamierza się wykonać. Do planów należy dołączyć obliczenia statyczne"16. Z treści pism przesłanych do KUL w roku 1947 przez Wydział Budownictwa Zarządu Miejskiego w Lublinie wynika, że było dużo życzliwości i zrozumienia dla starań o budowę pomieszczeń dla uczelni. Niestety, KUL nie posiadał dokumentacji budowlanej wymaganej przez urząd. Powstała konieczność wykonania nowych projektów.

Opracowanie nowych planów architektonicznych gmachu już budowanego dla innych celów, z zachowaniem wymagań władz budowlanych i z uwzględnieniem potrzeb KUL, było zadaniem trudnym i pilnym. Podobno inżynierowie nie chcieli podjąc się sporządzenia nowych planów ${ }^{17}$. Na prośbę Rektora KUL ks. A. Słomkowskiego, wykonaniem i realizacją tych projektów zajął się inż. architekt Ignacy Kędzierski (1877-1968), zdolny i znany w Polsce architekt. Od 1920 roku mieszkał i pracował w Lublinie jako architekt miejski. Był również kierownikiem Wydziału Budowlanego Zarządu Miasta przez niemal cały okres międzywojenny. W latach 1922-1923 zrealizował projekt budynku „Bobolanum” - Studium Misyjnego OO. Jezuitów przy Al. Racławickich (obecnie Szpital Wojskowy). Według jego projektu wzniesiono budynek Izby Skarbowej przy ul. Spokojnej (obecnie Urząd Wojewódzki), budynek szkoły powszechnej na Czwartku, szkoły zawodowej przy ul. Spokojnej i inne obiekty. Zgodnie z jego koncepcją wytyczono nowe arterie w Lublinie - Aleje Piłsudskiego i Aleje Zygmuntowskie. Brał on również udział w przygotowaniu planu zagospodarowania Lublina i tworzeniu nowych dzielnic. Po wojnie pracował jako projektant-urbanista w „Mia-

\footnotetext{
legającego bezpośrednio do istniejącego gmachu, tworząc jeden zharmonizowany i funkcjonalny budynek (o zróżnicowanej architekturze) - z nazwą: Katolicki Uniwersytet Lubelski Jana Pawła II Biblioteka Uniwersytecka ul. Chopina 27. W trudne prace związane z budową nowej części gmachu biblioteki według projektu inż. arch. Jerzego Grochulskiego, od strony ul. Chmielarczyka, o kubaturze ok. $10000 \mathrm{~m}^{3}$, które trwały w latach 1998-2008 był bardzo zaangażowany ks. dr Tadeusz Stolz, Dyrektor Biblioteki Uniwersyteckiej KUL.

${ }^{16}$ AU KUL, Korespondencja Władz KUL z Zarządem Miejskim, Wydział Budownictwa w Lublinie z lat 1947-1951; APL, Akta Nieruchomości.

${ }^{17}$ J. Warzeszak, Ks. Antoni Stomkowski 1900-1982 Rektor i odnowiciel KUL, teolog-rekolekcjonista, człowiek sumienia, Warszawa 1999, s. 34
} 
stoprojekcie" i opracowywał plany odbudowy Starego Miasta ${ }^{18}$. Po utworzeniu Komitetu Budowy Uniwersytetu Lubelskiego w 1921 roku wchodził w jego skład jako naczelny architekt Lublina. Po powołaniu Komitetu Odbudowy Katedry Lubelskiej (5 września 1945 roku) był jego członkiem w dziesięcioosobowej sekcji artystyczno-budowlanej. Przewodniczącym Komitetu został bp M. Fulman. Z opublikowanych wspomnień lubelskiego architekta Czesława Gawdzika wynika, że I. Kędzierski obok talentu architektonicznego i malarskiego posiadał życzliwy stosunek do ludzi oraz „franciszkańską skromność i prostotę"19.

Władze KUL zdecydowały, że w części budynku Akcji Katolickiej (w pierwszym etapie prac adaptacyjnych) zostanie utworzona nowa biblioteka główna z pozostawieniem na pewien okres istniejącej dużej nieukończonej sali widowiskowej. Natomiast w drugiej części gmachu określanej jako dom biurowy Akcji Katolickiej, gdzie istniały już fundamenty, planowano wybudowanie domu profesorów. W tej sytuacji arch. I. Kędzierski, spełniając postulaty władz miejskich i KUL, opracował dwa nowe projekty: „Plan pomieszczenia Biblioteki KUL w budynku sali Akcji Katolickiej Chopina 27, szkielet, mury, stropy wykonane wg planów inż. Siennickiego” oraz „Plan rozbudowy Domu Akcji Katolickiej Chopina 27 - mieszkania profesorów KUL i Biura Akcji Katolickiej Caritas, mury piwnic i parteru wykonane wg planów inż. J. Siennickiego" 20 . W dniu 22 września 1947 roku projekty te, z pozwoleniem na ich realizację, zatwierdził w imieniu Prezydenta Miasta Naczelnik Wydziału Budownictwa inż. Henryk Zamorowski, który w latach 1937-1939 akceptował plany i obliczenia konstrukcyjne diecezjalnego Domu Katolickiego opracowane przez arch. J. Siennickiego.

Zgodnie $\mathrm{z}$ planem, prace budowlane $\mathrm{w}$ gmachu rozpoczęto pod kierunkiem arch. I. Kędzierskiego we wrześniu 1947 roku w części pomieszczeń południowo-wschodnich obok sali widowiskowej oraz od strony ul. Chopina w ryzalicie. Dla nowej biblioteki przeznaczono przestrzeń $6.873 \mathrm{~m}^{3}$ o powierzchni użytkowej ok. $2.100 \mathrm{~m}^{3}$; kubatura całego gmachu głównego z salą widowiskową wynosiła ok. $25.000 \mathrm{~m}^{3}$.

Uwzględniając potrzeby biblioteki, zaprojektowano dużą czytelnię główną z balkonem na księgozbiór podręczny, czytelnię czasopism, gabinet zbiorów specjalnych, wypożyczalnię, pomieszczenia dla pracowników i kierownictwa biblioteki, salę na katalogi, hall z szatnią, introligatornię i inne niezbędne pomieszczenia. Magazyny zlokalizowano $\mathrm{w}$ ryzalicie, to jest w bezpośrednim sąsiedztwie planowanego domu biurowo-mieszkalnego. Wybudowano dla nich cztery piętra systemem wieżowym, do wysokości równej z projektowanym dachem domu biurowego (obecnie są to tzw. stare magazyny). W związku z brakiem miejsca na zbiory liczące wówczas ponad 300.000 woluminów, władze budowlane miasta, na prośbę Rektora KUL, w dniu 14 czerwca 1949 roku, wydały pozwolenie na nadbudowę zaprojektowanej dodatkowej kondygnacji magazynowej o kubaturze

${ }^{18}$ G. Jakimińska, Ignacy Kędzierski w: Stownik biograficzny miasta Lublina, t. 2, Lublin 1996, s. 101-103.

${ }^{19}$ Cz. Gawdzik, Architekt (I. Kędzierski), ,, Kurier Lubelski”, 1968, nr 290, s. 3.

${ }^{20}$ APL, Akta nieruchomości położonej w Lublinie przy ul. Chopina 27. 
$1.131 \mathrm{~m}^{3}$ oraz podwójnej wysokości, tj. do poziomu dachu budynku głównego ${ }^{21}$. Nadbudowa ta została wkrótce podzielona na dwa poziomy magazynowe lekką konstrukcją z drewna, by nie przeciążać fundamentu budynku. Pomieszczenie to w roku 1971 po uzyskaniu przez Bibliotekę Uniwersytecką KUL nowych magazynów, zostało przekazane na pracownię dla Redakcji Encyklopedii Katolickiej.

Budowa magazynów w ryzalicie była uciążliwa, gdyż trzeba było wykonać nowe stropy o odpowiedniej konstrukcji z zastosowaniem belek stalowych, trudno dostępnych w handlu. Należy również wspomnieć, że z zachowanych w archiwum obliczeń statycznych Domu Akcji Katolickiej, opracowanych przez arch. J. Siennickiego w roku 1937 wynika, że w tej części gmachu planowano utworzyć kaplicę 22 .

Niemal równocześnie z budową biblioteki przystąpiono do realizacji domu profesorów według planu opracowanego przez arch. I. Kędzierskiego, który różnił się od projektu opracowanego przed 1939 rokiem, uwzględniał bowiem potrzeby KUL i sugestie Rektora ks. A. Słomkowskiego. Budowany dom niemal w całości był przeznaczony na mieszkania dla profesorów i pracowników Uniwersytetu z wydzieleniem niewielkich pomieszczeń na biura i magazyny Akcji Katolickiej „Caritas”, która przez kilka lat po wojnie mogła służyć pomocą społeczeństwu w ramach struktur Kościoła. Zarezerwowano również kilka pokoi na parterze dla Kurii Biskupiej, ale nie były one wykorzystywane. Przez pewien okres część domu pełniła funkcję domu akademickiego dla studentek. Znalazły się także pokoje gościnne dla dojeżdżających na KUL wykładowców. Jeden z pokojów na trzecim piętrze został przeznaczony na kaplicę, która jest miejscem modlitwy i integracji mieszkańców domu. W budynku zamieszkało kilka sióstr zakonnych ze Zgromadzenia SS. Obliczanek (Zgromadzenie Sióstr Wynagrodzicielek Najświętszego Oblicza), które zatrudnione były w introligatorni biblioteki, opiekowały się kaplicą, jak również służyły pomocą w pracach porządkowo-administracyjnych. W latach osiemdziesiątych władze uniwersyteckie umieściły w domu profesorów: Towarzystwo Naukowe KUL, Biuro Zarządu Głównego Towarzystwa Przyjaciół KUL oraz kilka zakładów międzywydziałowych: Ośrodek Badań nad Polonią i Duszpasterstwem Polonijnym, Ośrodek Archiwów, Bibliotek i Muzeów Kościelnych, Ośrodek Badań nad Antykiem Chrześcijańskim. Powodem umieszczenia tych instytucji były trudności lokalowe w gmachu głównym przy Al. Racławickich 14.

Dom Profesorów jest dużym obiektem mieszkalnym, ma trzy piętra, piwnice oraz dwie klatki schodowe. Kubatura jego ma $10.633 \mathrm{~m}^{3}$, a powierzchnia użytkowa ok. $3.500 \mathrm{~m}^{2}$, długość budynku wynosi $45 \mathrm{~m}$., szerokość $14 \mathrm{~m}$., a wysokość ok. $17 \mathrm{~m}$. Poniżej poziomu piwnic wybudowano kotłownię centralnego ogrzewania, która służyła również Bibliotece Uniwersyteckiej. Architekt I. Kędzierski zaplanował budowę dodatkowego czwartego piętra, jako poddasza, na części gmachu od strony podwórza, by nie zmieniać wyglądu budynku od strony ul. Chopina oraz zachować architekturę zharmonizowaną z istniejącym frontonem Biblioteki.

\footnotetext{
${ }^{21}$ Tamże.

22 Tamże.
} 
W pomieszczeniu nadbudowanym na poddaszu zaplanowano kuchnię z pokojem, łazienki, pralnię, suszarnię, magiel, natomiast w części piwnicznej zorganizowano pomieszczenie kuchenne ze stołówką, które wkrótce przeznaczono na mieszkania.

Z początkiem roku 1950 do nowych mieszkań zaczęli wprowadzać się pracownicy KUL. Na prośbę władz Uniwersytetu przybyło do Lublina kilku utalentowanych pracowników naukowych z innych ośrodków akademickich Polski, którzy zamieszkali w nowym domu, wzmacniając kadrę naukową KUL.

Prace budowlane w głównym budynku, gdzie urządzano bibliotekę oraz w planowanym budynku biurowo-mieszkalnym w tzw. skrzydle, gdzie budowano mieszkania profesorów, przebiegały dość sprawnie, chociaż architekt I. Kędzierski sygnalizował, że istniały trudności z uporządkowaniem i naprawą istniejących piwnic i stropu, gdyż Niemcy dokonali podczas okupacji licznych zmian. Część konstrukcyjną przebudowanego i nowo budowanego domu profesorów zgodnie z umową wykonała firma „Technika” - Przedsiębiorstwo Robót Budowlanych i Kolejowo-Drogowych w Lublinie, której KUL udzielił wszechstronnej pomocy w pracach budowlanych przez zakup materiałów, organizacji transportu oraz udostępnienie pomieszczenia $\mathrm{w}$ gmachu biblioteki na parterze od strony ul. Chopina na uruchomienie warsztatu stolarskiego, który funkcjonował do roku 1951. W opracowaniu wszystkich projektów nowej biblioteki uniwersyteckiej w istniejących murach Domu Akcji Katolickiej oraz nowym Domu Profesorów przez cały - ponad czteroletni - okres ich realizacji inż. arch. I. Kędzierski współpracował z KUL, był kierownikiem budowy i pełnił nadzór autorski. Sprawdzał również czy kosztorysy i rozliczenia prac zostały wykonane poprawnie.

Pracami związanymi z budową Biblioteki i Domu Profesorów interesował się żywo Rektor ks. Słomkowski - inicjator budowy oraz jego brat Leonard Słomkowski - kierownik Intendentury KUL. Ks. prof. Antoni Słomkowski-znakomity Rektor KUL w latach 1944-1951, profesor teologii dogmatycznej, brał osobiście udział we wszystkich sprawach uczelni, starał się być blisko pracowników i studentów. Interesował się bardzo ich potrzebami i kłopotami, obdarzony był również dużym talentem organizacyjnym. $Z$ oddaniem i zapałem dbał o odbudowę KUL oraz sprawnie kierował Uniwersytetem jako jego odnowiciel po zniszczeniach wojennych. Pomimo licznych trudności, miał silną wiarę w pomoc Opatrzności Bożej i czynił wszystko, by KUL stał się prężnym ośrodkiem nauki.

Działalność KUL stanowiła przeszkodę do wprowadzenia przez władze państwowe systemu komunistycznego w Polsce, gdyż rozwijająca się prężnie uczelnia posiadała katolicki charakter i cieszyła się dobrą opinią polskiego społeczeństwa. W latach 1949/1950 podjęto działania ograniczające i hamujące rozwój uniwersytetu, ponieważ KUL jako jedyny przyjmował na studia również młodzież, która miała „niewłaściwe” pochodzenie społeczne i nie mogła z tego powodu studiować na innych uczelniach. Atakowano KUL w środkach społecznego przekazu, aby ograniczyć jego oddziaływanie na społeczeństwo polskie. Władze oświatowe oskarżały Uniwersytet, że nie realizował wystarczająco obowiązującego programu nauczania i wychowania młodzieży w duchu ideologii marksistowskiej, lecz uwzględniał przede wszystkim wartości religijne, w duchu nauki Kościoła i pol- 
skiej tradycji narodowej. Za bezkompromisową postawę w obronie katolickiej tożsamości Uniwersytetu oraz odmowę zalegalizowania na KUL komórki partyjnej (ateistycznej) i organizacji młodzieżowej ZMP (Związek Młodzieży Polskiej) propagującej materialistyczny pogląd na świat, ks. A. Słomkowski został pozbawiony w 1951 roku przez Ministerstwo Szkolnictwa Wyższego funkcji Rektora. W 1952 roku aresztowano go i po procesie sądowym, z oskarżenia o posiadanie dolarów ofiarowanych przez Polonię amerykańską dla KUL oraz nielegalne przeznaczenie ich na potrzeby związane $\mathrm{z}$ funkcjonowaniem Uniwersytetu, skazano jako „wroga Polski Ludowej”, na ciężkie więzienie (1952-1954).

Praca Rektora ks. A. Słomkowskiego nad odbudową i rozwojem Uniwersytetu była wysoko oceniana przez Episkopat Polski, prymasa Augusta Hlonda oraz przez Wielkich Kanclerzy KUL. Budowa nowej biblioteki była ważnym wydarzeniem dla prof. Andrzeja Wojtkowskiego, dyrektora biblioteki KUL w latach 1944-1949, wybitnego uczonego i bibliotekarza, przed wojną dyrektora Biblioteki Raczyńskich w Poznaniu. W dniu 6 listopada 1949 roku Prymas S. Wyszyński poświęcił nowy budynek Biblioteki KUL. Opracowany projekt stwarzał możliwość dalszej przebudowy całego gmachu dla potrzeb biblioteki, co zrealizowano, pokonując liczne trudności w późniejszym czasie, bez zakłóceń w świadczeniu usług czytelnikom. Po szybkim wyposażeniu wnętrz i przeniesieniu księgozbioru ze starego pobernardyńskiego gmachu - książnica ta od 1950 roku przez długi okres była jedyną biblioteką naukową w Lublinie i cieszyła się bardzo dobrą opinią czytelników. Zatem właśnie rok 1950 można traktować jako przełomowy w historii Biblioteki KUL. W tym też roku na stanowisko dyrektora biblioteki został powołany przez Senat Akademicki KUL wybitny bibliotekarz i bibliograf o. dr Romuald Gustaw OFMBern.

Budowa dwuczęściowego gmachu przy ul. Chopina 27 była połączona $\mathrm{z}$ dużym wysiłkiem materialnym i organizacyjnym KUL, ale miała wsparcie Episkopatu na czele z Prymasem A. Hlondem i bp S. Wyszyńskim, duchowieństwa i społeczeństwa katolickiego. Prace były prowadzone w atmosferze pewnego zagrożenia ze strony ośrodków nieprzychylnych Kościołowi i KUL, co niestety ujawniło się wkrótce, gdyż władze miasta próbowały zająć część gmachu dla swoich potrzeb. W tym okresie około 10 arów działki należącej do $\mathrm{Ku}-$ rii Biskupiej przy ul. Chopina 27 (od strony ul. Lipowej) przejął Zarząd Miasta i wybudowano tam budynek mieszkalny.

Roboty budowlane przebiegały sprawnie, chociaż były problemy z zakupem stali, cementu i innych materiałów. Wielkie zaangażowanie i ofiarność przy budowie wykazywali pracownicy fizyczni, w szczególności stolarnia uniwersytecka oraz Intendentura KUL.

Powołana w roku akademickim 1949/1950 Senacka Komisja Kontrolna oceniła, że budowa gmachu przy ul. Chopina 27 przeznaczonego na bibliotekę i mieszkania dla profesorów została wykonana dobrze i oszczędnie, podkreślając, że organizacja pracy była doskonała.

Po zakończeniu prac związanych z budową Biblioteki i Domu Profesorów KUL oraz sporządzeniu kolaudacji arch. I. Kędzierski prosił władze Uczelni o zwolnienie $\mathrm{z}$ dotychczasowych obowiązków. Jego praca wykonana z sumienno- 
ścią i talentem posiada do dnia dzisiejszego wielką wartość dla Uczelni. Należy też przypomnieć, że architekt chętnie przyszedł z pomocą dla KUL, by trud budowy Domu Katolickiego dla Akcji Katolickiej podjęty przez bpa M. Fulmana, przerwany przez wojnę, nie został zaniechany i zaprzepaszczony w trudnym powojennym okresie. Dzięki życzliwej i dalekowzrocznej decyzji bpa S. Wyszyńskiego oraz wielkiemu zaangażowaniu i poświęceniu Rektora ks. A. Słomkowskiego, nieukończone wielkie dzieło bpa M. Fulmana, mogło być realizowane przez KUL dla innych celów, wspierając potrzeby naukowe Uniwersytetu służącego zgodnie ze swoją dewizą „Bogu i Ojczyźnie”.

Arcybiskup Bolesław Pylak w monografii Stefan Wyszyński Biskup Lubelski 1946-1949 napisał, że „nasza Katolicka Uczelnia zawdzięcza ks. biskupowi Wyszyńskiemu bardzo wiele"23. Uczestniczył on przez wiele lat najpierw jako Wielki Kanclerz KUL, potem Przewodniczący Komisji Episkopatu do spraw KUL we wszystkich ważnych jego problemach i wydarzeniach.

Gdy rozpatrujemy, z niemal stuletniej perspektywy czasowej dzieje Katolickiego Uniwersytetu Lubelskiego, należy podkreślić, że na szczególną pamięć i wdzięczność zasługuje Rektor KUL ks. Idzi Radziszewski (1871-1922). Był on inicjatorem i głównym założycielem Uniwersytetu. Z wielkim poświęceniem, wytrwałą pracą, silną wiarą, pomimo licznych trudności i przeciwności, stworzył dzieło, które służy do dnia dzisiejszego.

$\mathrm{W}$ prace związane $\mathrm{z}$ współtworzeniem Uniwersytetu oraz jego funkcjonowaniem przez wiele lat był także zaangażowany bp Marian Fulman - Wielki Kanclerz Katolickiego Uniwersytetu Lubelskiego.

Można wyrazić również przekonanie, że Katolicki Uniwersytet Lubelski swoje odrodzenie po drugiej wojnie światowej, a następnie rozwój i przetrwanie w bardzo trudnym okresie komunistycznej Polski zawdzięcza mądrości, odwadze i dalekowzroczności wielkich osobowości, które kierowały Uniwersytetem. Byli to przede wszystkim Rektor ks. Antoni Słomkowski - odnowiciel KUL oraz bp S. Wyszyński - Wielki Kanclerz, potem Prymas i Kardynał, który przypomnianą $\mathrm{w}$ tym opracowaniu decyzją objawił w pełni swą przyszłą rolę nieustraszonego i skutecznego opiekuna i obrońcy Uniwersytetu.

\section{Źródla}

\section{BIBLIOGRAFIA}

Archiwum Katolickiego Uniwersytetu Lubelskiego (AU KUL)

Korespondencja Władz KUL z Zarządem Miejskim, Wydział Budownictwa w Lublinie $\mathrm{z}$ lat $1947-1951$.

Materiały związane z budową Biblioteki KUL oraz Domu Profesorów przy ul. Chopina 27-29 w latach 1947-1951.

Akta notarialne.

Archiwum Państwowe w Lublinie (APL)

sygn. 5318: Akta nieruchomości położonej w Lublinie przy ul. Chopina 27, Akta miasta Lublina, Inspekcja Budowlana.

${ }^{23}$ B. Pylak, Stefan Wyszyński Biskup Lubelski 1946-1949, Lublin 2000, s. 165. 
Biblioteka Uniwersytecka Katolickiego Uniwersytetu Lubelskiego (BU KUL)

Zbiory ikonograficzne.

Państwowe Muzeum na Majdanku

Zbiór fotografii XVII, kolekcja nr 6.

Zbiory własne autora - Franciszka Chwalewskiego

Fotografie.

\section{Opracowania}

Adamski Stanisław, Akcja Katolicka Młodzieży, Poznań 1937.

Adamski Stanisław, Podstawy pracy Stowarzyszeń i Akcji Katolickiej, Poznań 1937.

Biblioteka Uniwersytecka Katolickiego Uniwersytetu Lubelskiego 1918-1970, „Archiwa Biblioteki i Muzea Kościelne”, 23 (1971) s.19-212.

Biskup Lubelski Marian Leon Fulman Pedagog trudnych lat, red. Edward Walewander, Lublin 2010.

Brzostowska Zofia, Rodzinie katolickiej - z tamtych lat, w: Katolicki Uniwersytet Lubelski w latach 1944-1952 Wspomnienia i relacje, red. Jan Ziółek, Lublin 1999, s. 111-115.

Chwalewski Franciszek, Wspomnienie o Ojcu Romualdzie Gustawie OFM Bern. Dyrektorze Biblioteki Uniwersyteckiej KUL w latach 1950-1976, „Archiwa Biblioteki i Muzea Kościelne", 106 (2016), s. 443-462.

Cichocki Jerzy, KUL pracuje (przedruk z „Tygodnika Powszechnego”) w: „Deo et Patriae” Katolicki Uniwersytet Lubelski, Lublin 1948, s. XII-XXX.

Działalność Katolickiego Uniwersytetu Lubelskiego w czasie okupacji (relacje i dokumenty), red. Jan Ziółek, Lublin 1983.

Gawdzik Czesław, Architekt (I. Kędzierski), ,, Kurier Lubelski”, 1968, nr 290, s. 3.

Goliński Zdzisław, Fulman Marian Leon (1866-1945), w: Polski Słownik Biograficzny, T. 7, Kraków-Wrocław 1948-1958, s. 181-183.

Goliński Zdzisław, Pierwszy Wielki Kanclerz KUL. Pamięci Księdza Biskupa Mariana Leona Fulmana, w: Katolicki Uniwersytet Lubelski „Deo et Patriae”, Lublin 1947, s.7-14.

Gustaw Romuald, Nowodworski Witold, Dwadzieścia lat Biblioteki Uniwersyteckiej, „Archiwa Biblioteki i Muzea Kościelne”, 1 (1960) z. 2, s. 133-160.

Jakimińska Grażyna, Ignacy Kędzierski, w: Słownik biograficzny miasta Lublina, t. 2, Lublin 1996, s. 101-103.

Jaźwierska Jadwiga, Z dziejów przebudowy gmachu Biblioteki Uniwersyteckiej KUL, „Roczniki Humanistyczne”, 55 (2007) z.4, s. 91-117.

Karolewicz Grażyna, Karol Jaroszyński (1877-1929) fundator Katolickiego Uniwersytetu Lubelskiego, Lublin 2000.

Karolewicz Grażyna, Ksiąz Idzi Benedykt Radziszewski 1871-1922, Lublin 1998.

Katolicki Uniwersytet Lubelski „Deo et Patriae”, Lublin 1947.

Katolicki Uniwersytet Lubelski Jana Pawta II: 90. lat istnienia, red. Grzegorz Kramarek, Eugeniusz Ziemann, Lublin 2008.

Katolicki Uniwersytet Lubelski w latach 1944-1952, Wspomnienia i relacje, red. Jan Ziółek, Lublin 1999.

Komunikat Polsko-Sowieckiej Komisji Nadzwyczajnej dla Zbadania Zbrodni Niemieckich dokonanych $w$ obozie zniszczenia na Majdanku $w$ m. Lublinie, „Rzeczpospolita”, 1944, nr 45, s. 4-6.

Ksiądz Rektor Antoni Słomkowski. Stulecie urodzin. Materiały z sympozjum KUL 5 grudnia 2000 r., red. Marek Chmielewski, Lublin 2001. 
Księga Jubileuszowa 50-lecia Katolickiego Uniwersytetu Lubelskiego, praca zbiorowa, Lublin 1969.

Księga Pamiatkowa ku czci Jego Ekscelencji X. Biskupa Mariana Leona Fulmana, cz. 1-3: Część I: Wydział Teologiczny, Wydział Prawa Kanonicznego, Część II: Wydział Prawa i Nauk Społeczno-Ekonomicznych, Część III: Wydział Nauk Humanistycznych, Lublin 1939.

Kufel Zbigniew, Z dziejów kaplicy w domu profesorskim KUL, „Przegląd Uniwersytecki”, 2014, nr 2, s. 45-46.

Kulik Zbigniew, Bt. Stanisław Kostka Starowieyski 1895-1941 działacz Akcji Katolickiej. Cztery tajemnice zwykłego człowieka, Sandomierz 2015, wyd. II, s. 178-179.

Micewski Andrzej, Kardynat Wyszyński. Prymas i mą̇̇ stanu, Paris 1982.

Niparko Romuald, Akcja Katolicka, w: Encyklopedia Katolicka, t. 1, Lublin 1973, kol. 227-233.

Nowodworski Witold, Gmach Biblioteki, „Archiwa Biblioteki i Muzea Kościelne”, 23 (1971) s. 53-59.

Piotrowski Stanisław, Misja Odyla Globocnika. Sprawozdanie o wynikach finansowych zagłady Żydów w Polsce, Warszawa 1949.

Pylak Bolesław, Stefan Wyszyński Biskup Lubelski 1946-1949, Lublin 2000.

Rektorowi KUL w 90. rocznicę śmierci ks. Idziego Radziszewskiego, redakcja Stanisław Janeczek, Marzena Krupa, Lublin 2013.

Romaniuk Marian Piotr, Kardynat Stefan Wyszyński. Rys biograficzny w trzydziesta rocznicę narodzin dla nieba. Biografia, teksty źródłowe, kult, Gniezno 2011.

Romaniuk Marian Piotr, Życie, twórczość, postuga Prymasa Tysiaclecia, T. 1-4, Warszawa 1994-2002.

Słomkowski Antoni, Wielki Kanclerz K.U.L. w: Na ingres Księdza Prymasa. Jednodniówka Katolicka, 6 II 1949, Warszawa 1949.

Słomkowski Antoni, Wspomnienia z czasów petnienia obowiązów Rektora KUL w: Katolicki Uniwersytet Lubelski w latach 1944-1952, Lublin 1999, s. 25-85.

Walewander Edward, Biskup Marian Leon Fulman (1866-1945) - zycie i dzieło w: Biskup Lubelski Marian Leon Fulman Pedagog trudnych lat, red. Edward Walewander, Lublin 2010, s. 123-130.

Warzeszak Józef, Ks. Antoni Słomkowski 1900-1982, Rektor i odnowiciel KUL, teolog - rekolekcjonista, człowiek sumienia. Warszawa 1999.

Wczoraj-dziś - jutro Akcji Katolickiej, praca zbiorowa pod redakcją T. Borutki, Kraków 2004.

„Wiadomości Diecezjalne Lubelskie”, R. 1932, nr 7, s. 208-217, R. 1938, nr 6-7, s.225226, R. 1945, nr 1-2, R. 1946, nr 1.

Wilk Stanisław, Biskup Marian Leon Fulman jako Wielki Kanclerz KUL w: Biskup Lubelski Marian Leon Fulman Pedagog trudnych lat, red. Edward Walewander, Lublin 2010, s. 131-145.

Wojtkowski Andrzej, Początki Biblioteki Głównej KUL, „Tygodnik Powszechny”, 1955, nr 47, s.7-8.

[Wyszyński Stefan] Prymas Tysiąclecia, wybór tekstów i opracowanie redakcyjne: F. Kniotek, Z. Modzelewski, D. Szumska, Paryż 1982.

Ziółek Jan, Poczatki powojennej działalności Uniwersytetu Lubelskiego, „Chrześcijanin w Świecie", 11 (1984) s. 30-39.

Ziółek Jan, Katolicki Uniwersytet Lubelski w latach 1944-1992, w: Księga pamiątkowa w 75-lecie Katolickiego Uniwersytetu Lubelskiego. Wkład w kulture polska w latach 1968-1993, red. Marian Rusecki, Lublin 1994, s. 31-55. 
DOM KATOLICKI

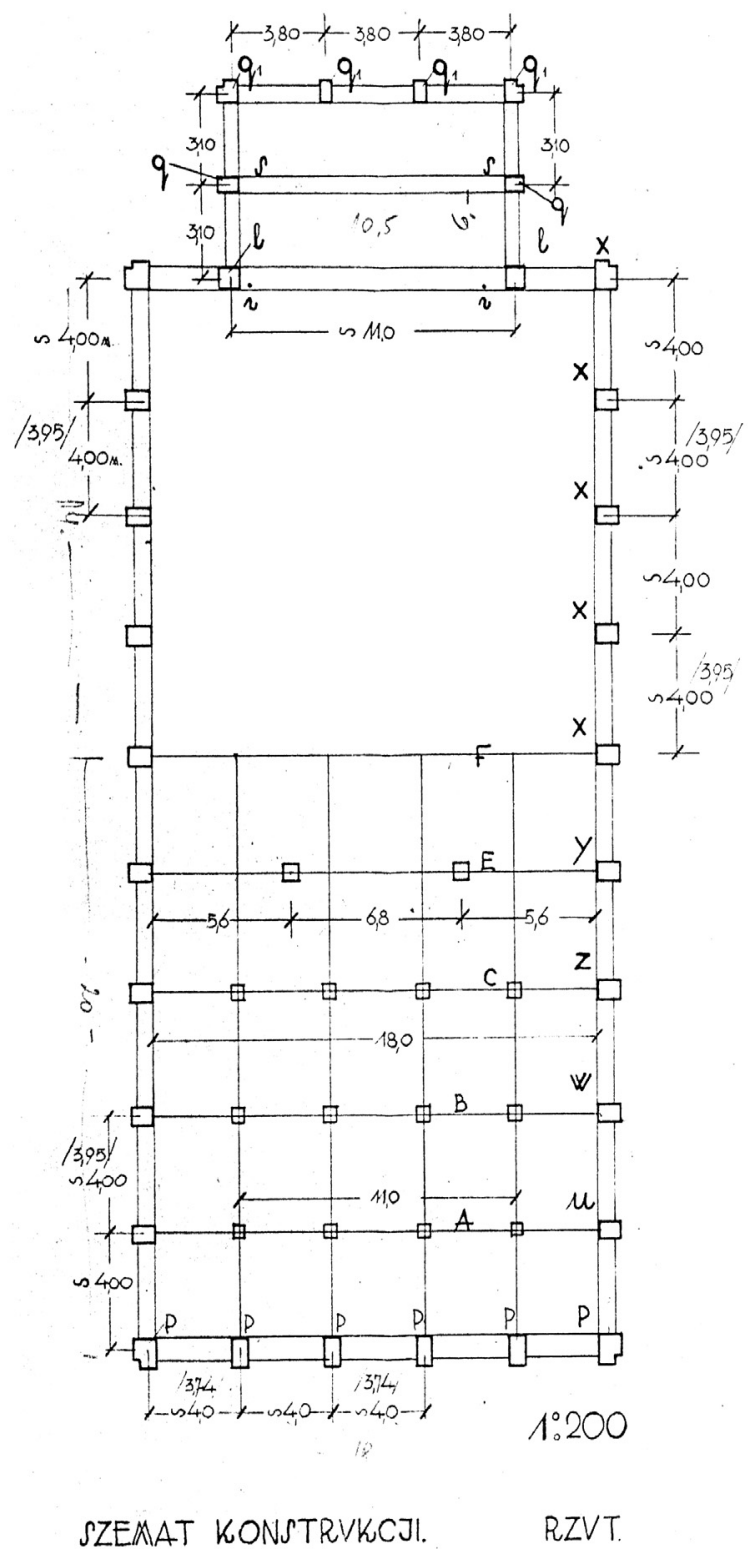

Fot 1. Dom Katolicki, schemat rzutu konstrukcji sali widowiskowej wg planu inż. arch. Jerzego Siennickiego z 1937 r.

Zbiory Archiwum Państwowego w Lublinie. 


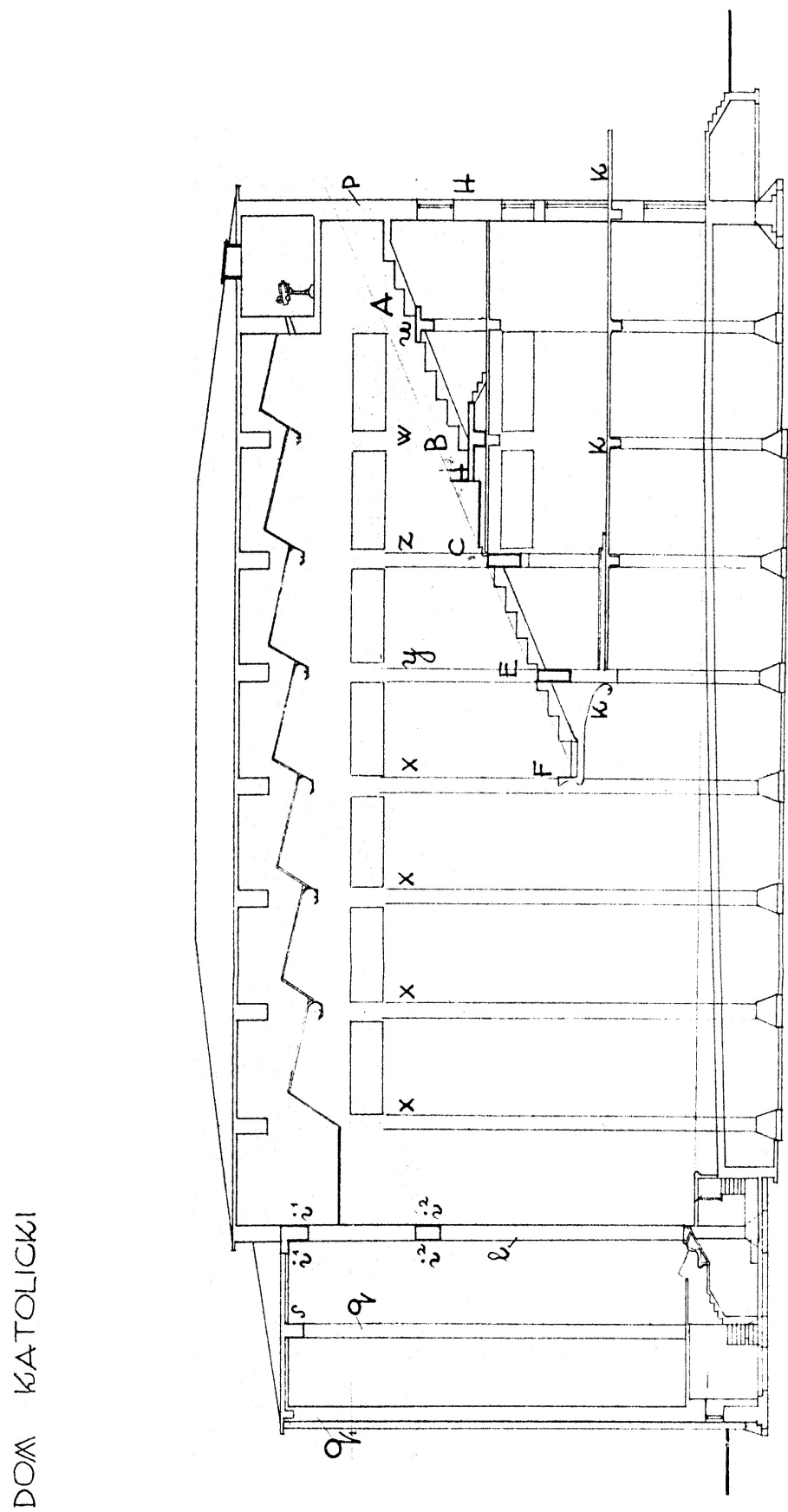

Oู

O0

$\cong$

荨

OD

$\frac{1}{3} \cdot 9$

กิ

2ิ 3

N

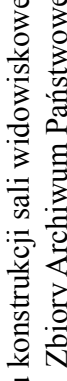

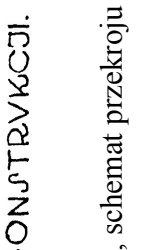

$\$$

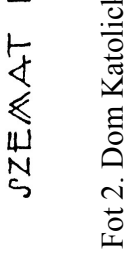




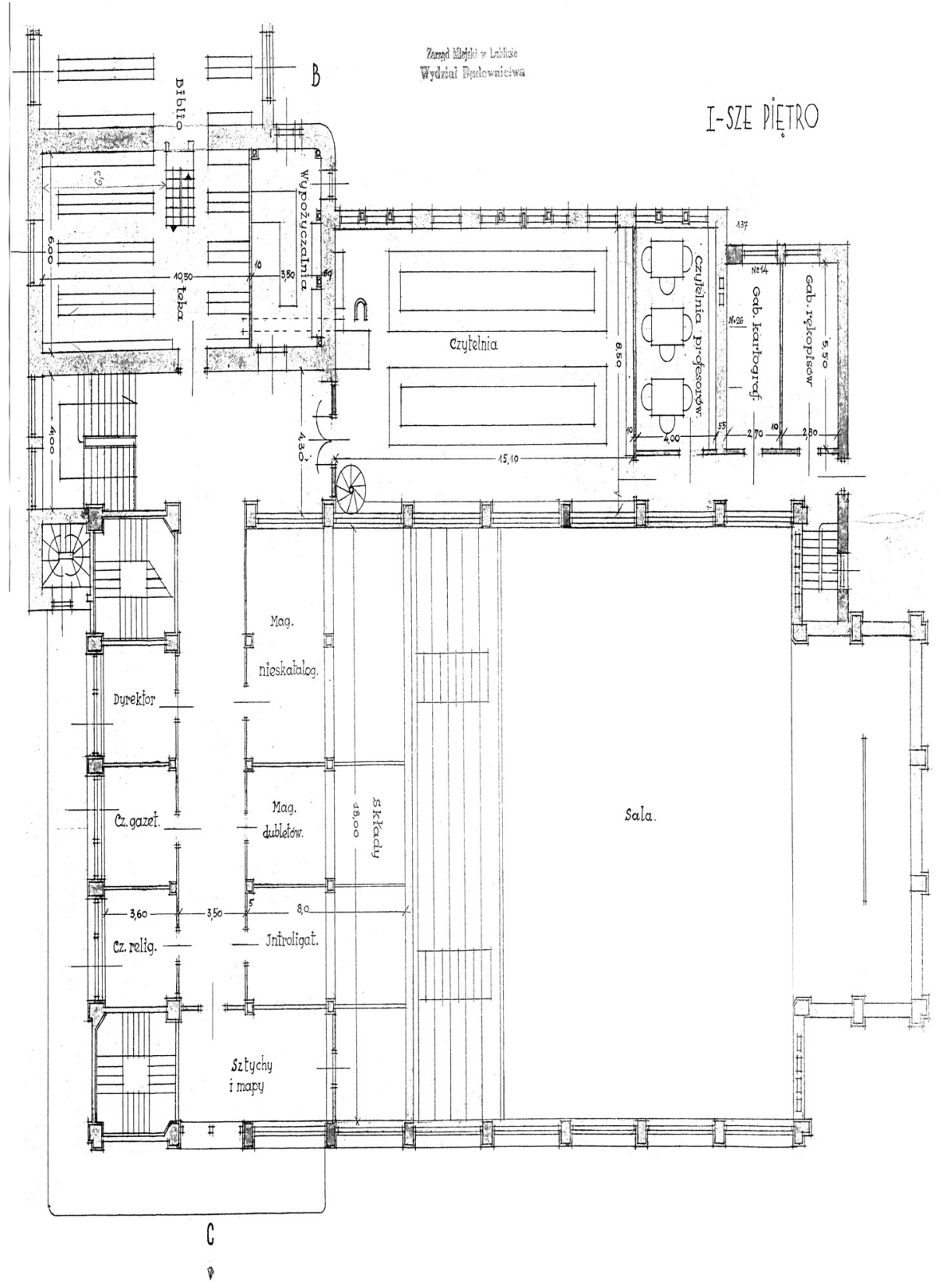

Fot. 3. Rzut pierwszego piętra Biblioteki Uniwersyteckiej KUL wg planu z 1947 r. opracowanego przez inż. arch. Ignacego Kędzierskiego (zatwierdzonego przez władze państwowe), zrealizowany z małymi zmianami w latach 1947-1950. Plan ten był wykonany na podstawie projektu Domu Akcji Katolickiej inż. arch. Jerzego Siennickiego w 1937 r. Zbiory Archiwum Państwowego w Lublinie. 


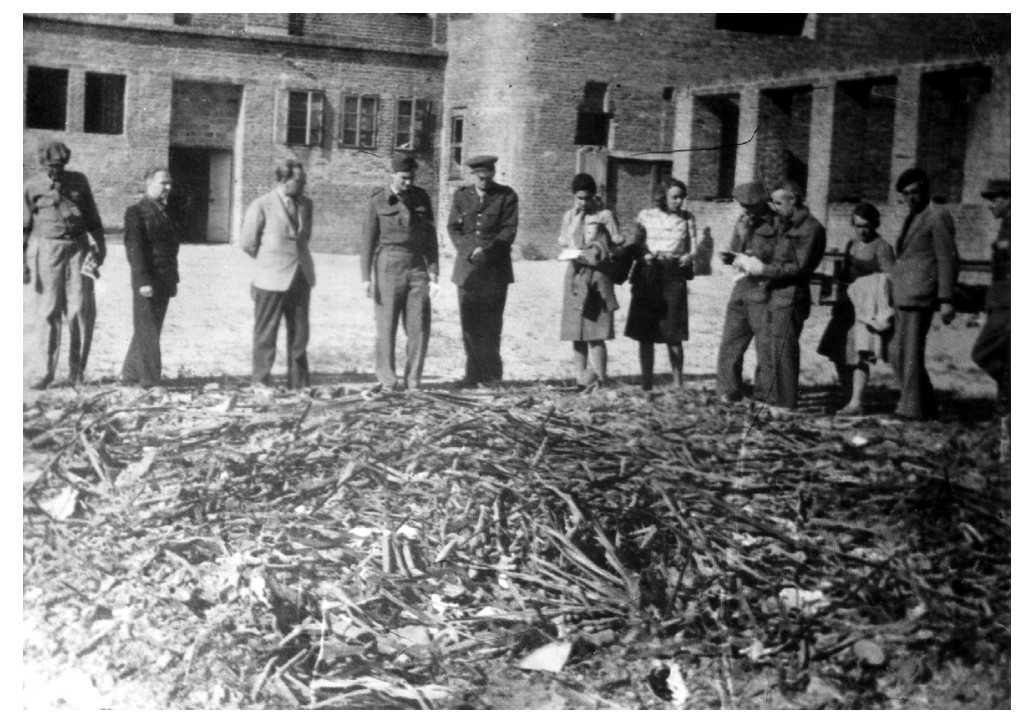

Fot. 4. Zagraniczni dziennikarze oglądają przed budynkiem przyszłej Biblioteki KUL zniszczone i pozostawione przez Niemców resztki opakowań po zrabowanych rzeczach ludności cywilnej oraz zamordowanych więźniów (1944). Zbiory Państwowego Muzeum na Majdanku.

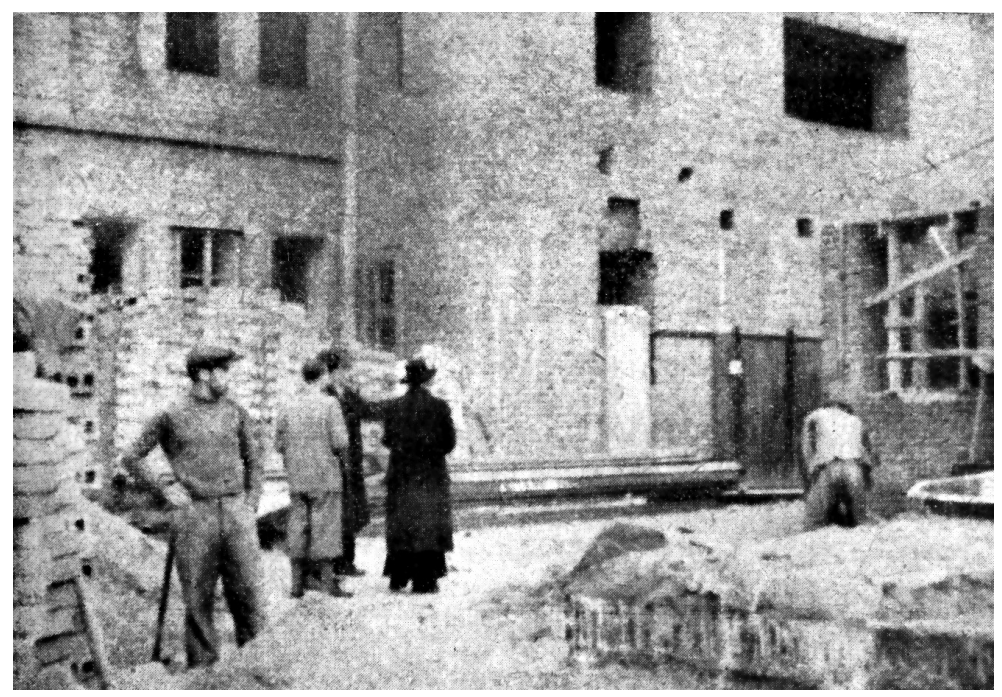

Fot. 5. Ks. Rektor Antoni Słomkowski przy budowie Biblioteki KUL (1947). Fot. z artykułu: Jerzy Cichocki, KUL pracuje, w: „,Deo et Patriae”. Katolicki Uniwersytet Lubelski, Lublin 1948, s. XXIII. 


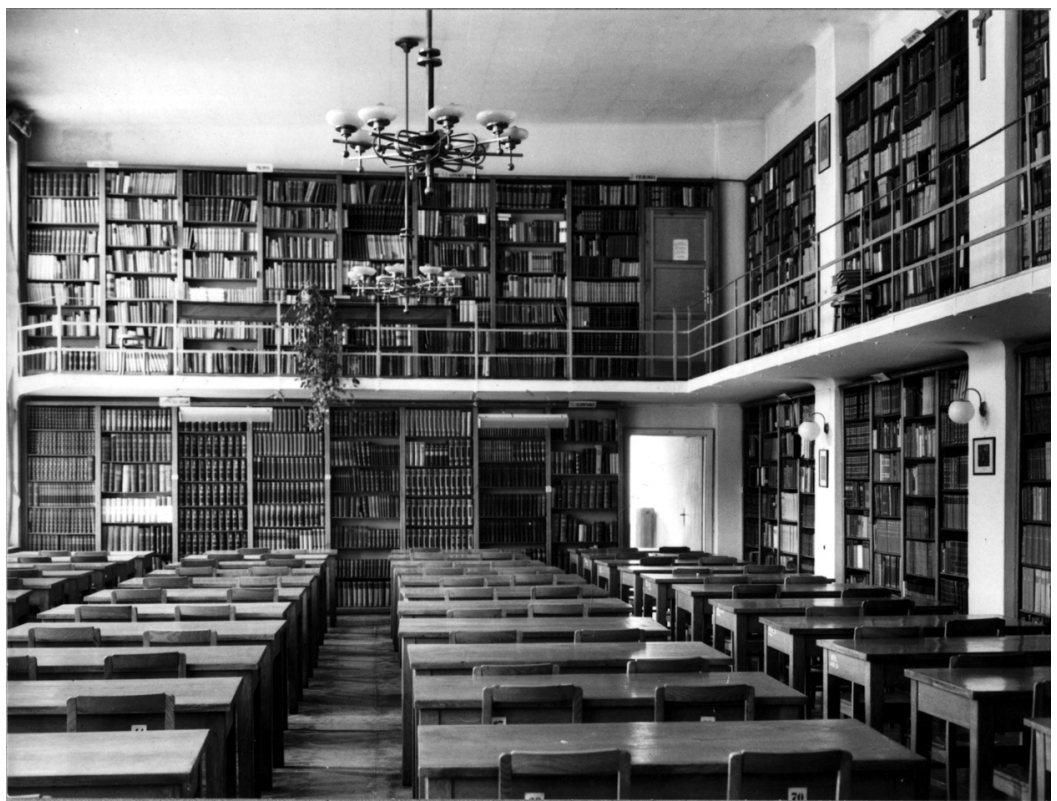

Fot 6. Widok Czytelni Głównej na I piętrze, po ukończeniu pierwszego etapu przebudowy gmachu, ok. 1950 r. Zbiory Biblioteki KUL.

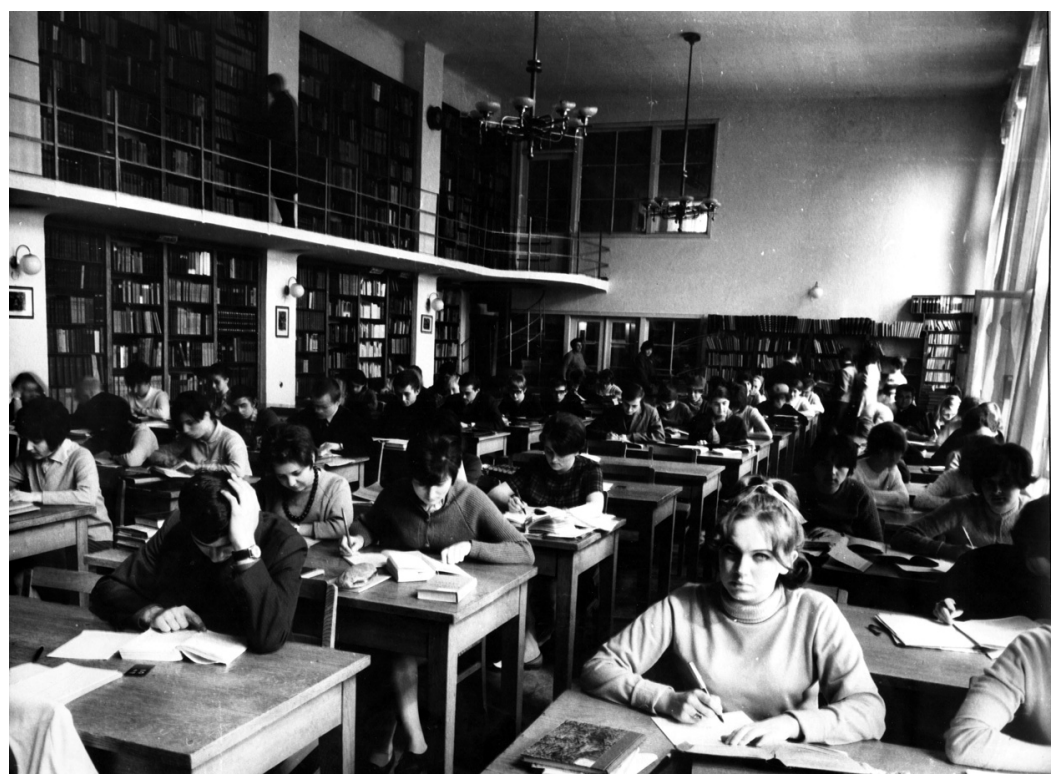

Fot. 7. Czytelnicy w Czytelni Głównej, ok. 1960 r. Zbiory Biblioteki KUL. 


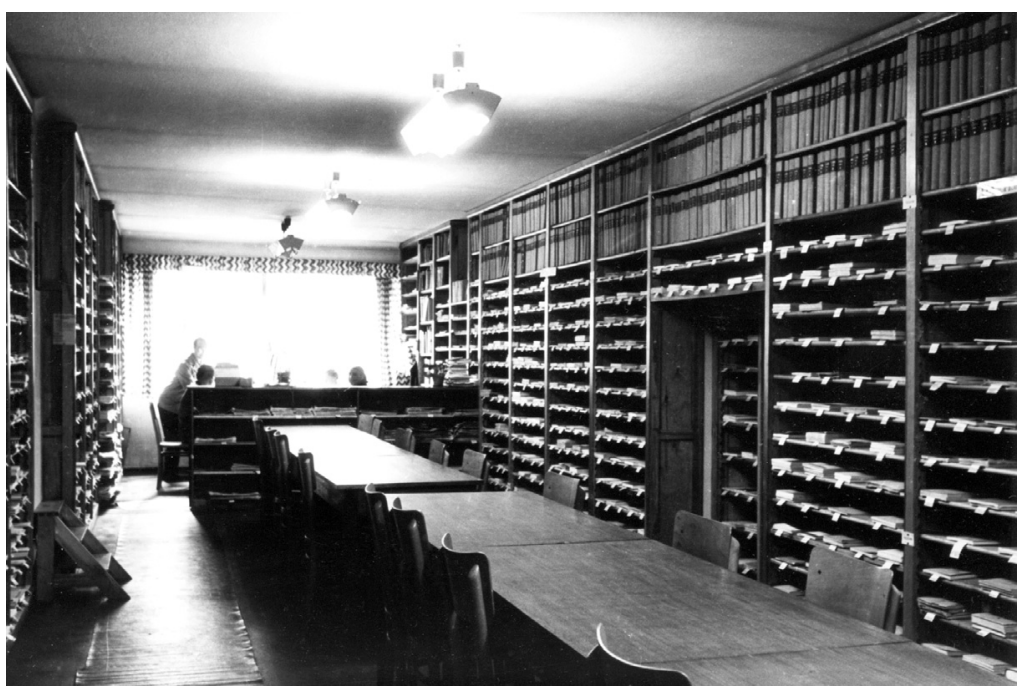

Fot 8. Czytelnia Czasopism na II piętrze, $\mathrm{z}$ wejściem z antresoli od strony Czytelni Głównej, ok.1955 r. Zbiory autora.

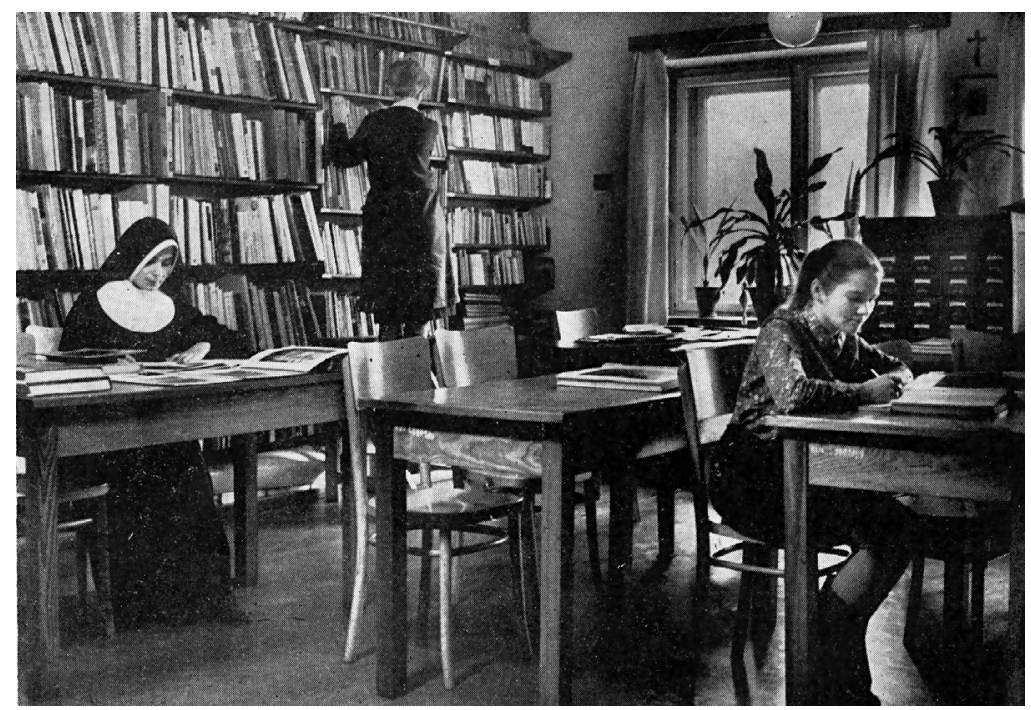

Fot. 9. Czytelnia Zbiorów Specjalnych, ok. 1955 r. Zbiory autora. 


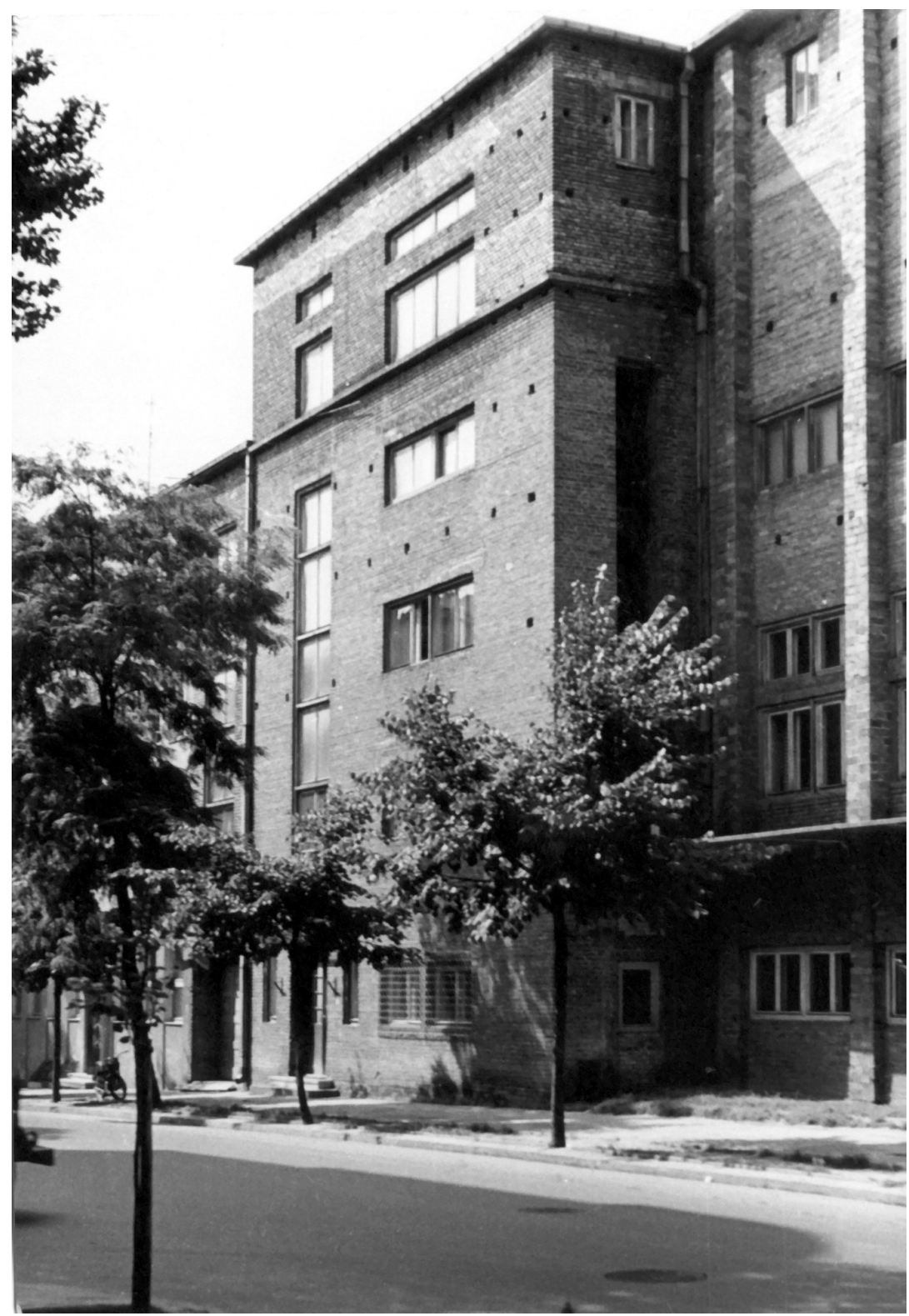

Fot. 10. Fasada Biblioteki KUL po pierwszym etapie przebudowy (1947-1950) według planu inż. arch. Ignacego Kędzierskiego, ok. 1955 r. Zbiory autora. 


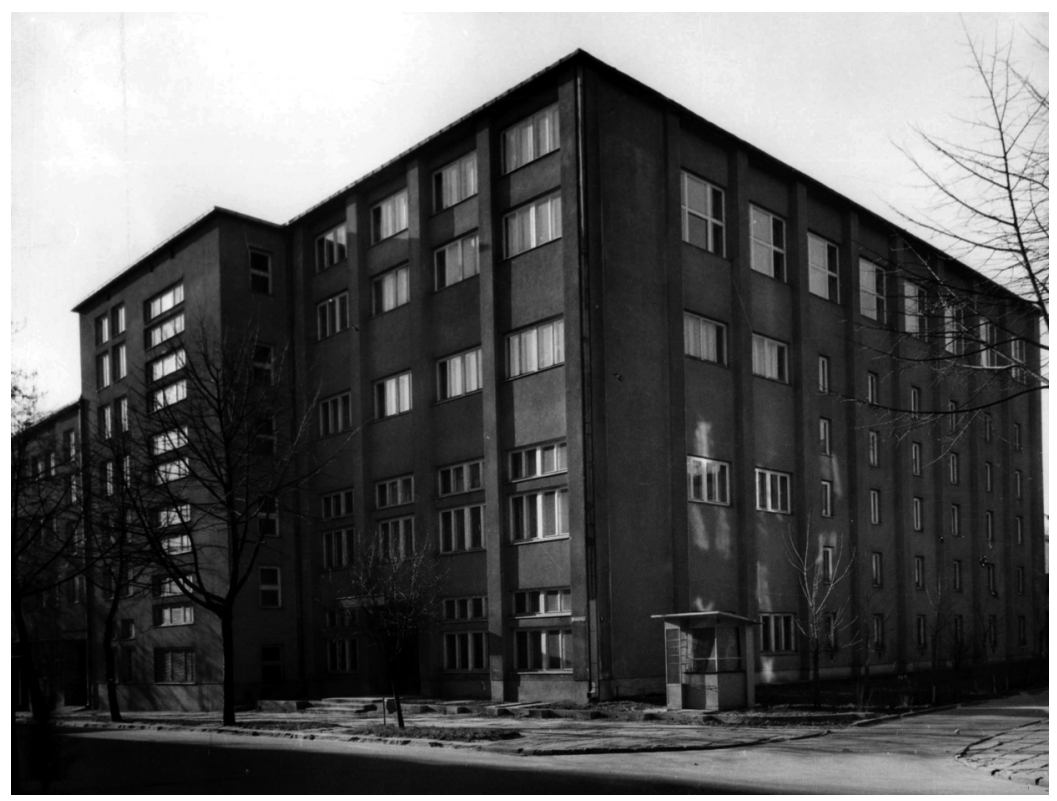

Fot. 11. Widok fragmentu Domu Profesorów oraz fasada Biblioteki KUL po drugim etapie pełnej adaptacji gmachu w latach 1960-1971, według projektu inż. arch.

T. Witkowskiego i inż. arch. Z. Zawory, przy dużym zaangażowaniu Dyrektora BU KUL o. dr R. Gustawa OFMBern., ok. 1972 r. Zbiory autora.

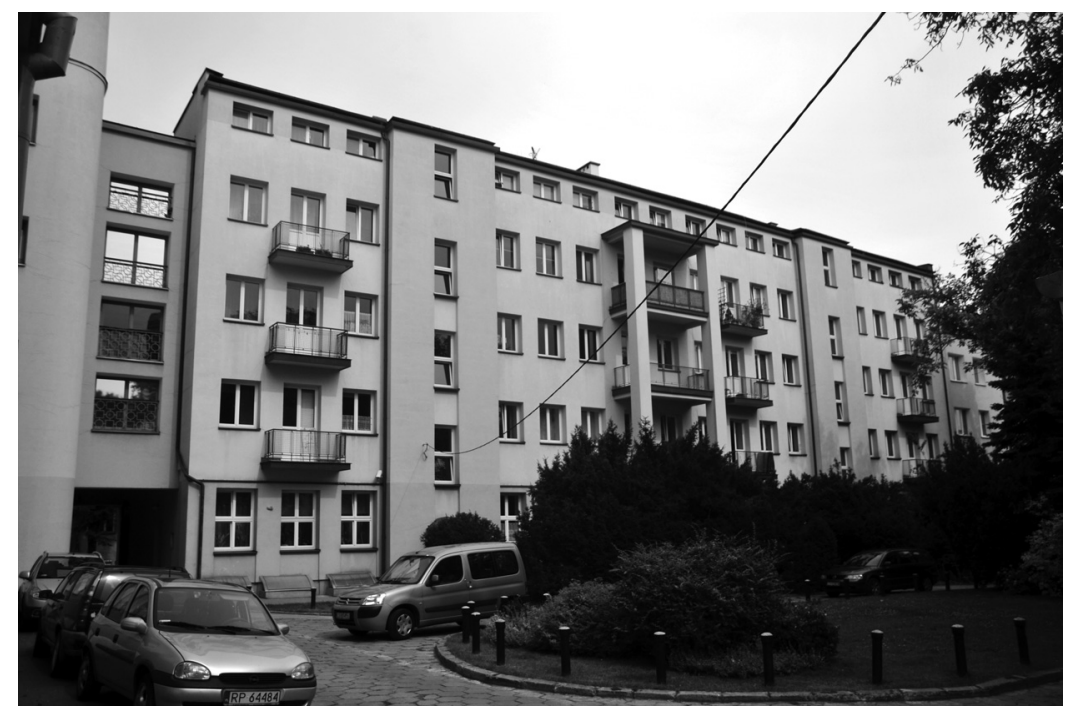

Fot. 12. Dom Profesorów od strony podwórza, 2017 r.

Fot. Arkadiusz Adamczuk. 